\title{
Analysis of Student Entrepreneurship decision making in the Learning Prerspective
}

\author{
Agus Syam ${ }^{1}$, Sudarmi $^{2}$ \\ ${ }^{1}$ Universitas Negeri Makasar \\ ${ }^{2}$ STIM Lasharan Jaya Makassar \\ E-mail: agussyam76feunm@gmail.com, sudarmi978@gmail.com²
}

(Received: March-2019; revised: April -2019; published: June -2019)

\begin{abstract}
The main problem of entrepreneurship education in Indonesia is the mindset of most Indonesian people that the goal of continuing education to higher education to become a civil servant is not to be someone who has an entrepreneurial mentality. Entrepreneurship learning has not been able to change the mind-set of college graduates from finding jobs (job seekers) to creating jobs (job creators). Therefore, the formulation of the problem in this study is, "Is there an influence of entrepreneurial learning on student decision making in entrepreneurship at Makassar State University. This study aims to find out, "The effect of entrepreneurial learning on student decision making in entrepreneurship at Makassar State University. This research is an Explanatory Research with a Survey approach with a population of 654 Makassar State University students who propose a Student Creativity Program (PKM) with a sample of 242 which is done by proportional random sampling technique. Therefore, the formulation of the problem in this study is, "Is there an influence of entrepreneurial learning on student decision making in entrepreneurship at Makassar State University. This study aims to find out, "The effect of entrepreneurial learning on student decision making in entrepreneurship at Makassar State University. This research is an Explanatory Research with a Survey approach with a population of 654 Makassar State University students who propose a Student Creativity Program (PKM) with a sample of 242 which is done by proportional random sampling technique. The technique of collecting data uses observation, questionnaires, and documentation. Data analysis using SEM. The results of the study show; "There is a significant effect of entrepreneurial learning on student decision making in entrepreneurship at Makassar State University.
\end{abstract}

Keywords: Decision Making, Entrepreneurship, and Learning

\section{INTRODUCTION}

The aim of national development carried out by the Indonesian people is to create a just and prosperous society that is material and spiritual evenly based on the Pancasila and the 1945 Constitution in the container of the Unitary State of the Republic of Indonesia, the goal of development is to reduce poverty and unemployment.

It is undeniable that Indonesia faces the problem of limited employment opportunities for college graduates with the increasing number of intellectual unemployment lately. The conditions faced will be further aggravated by the situation of global competition (eg the enactment of the ASEAN Economic Community / MEA) which will confront graduates of

Copyright (C) 2018 Universitas Negeri Makassar. This is an open access article under the CC BY license (http://creativecommons.org/licenses/by/4.0/) 


\section{2 | Jurnal Administrare: Jurnal Pemikiran Ilmiah dan Pendidikan Administrasi Perkantoran \\ Volume 6 No. 1 January-June 2019. Pages 51-60}

Indonesian universities competing freely with graduates from foreign universities. Therefore, college graduates need to be directed and supported not only to be job seekers but also to be able to become job creators as well.

Various challenges faced in the world of education in the current era of globalization require people especially educators and students to always increase their attention both in terms of concepts, objectives, material, methods, models, implementation and reseach in an effort to realize the goals of the education system (Farida, 2017; Niswaty, Rusbiati, Jamaluddin, \& Salam, 2017; Saggaf, Salam, \& Rifka, 2017; Salam, Rosdiana, Suarlin, \& Akib, 2014). Education is a conscious and planned effort to create a learning atmosphere and learning process so that students actively develop their potential or can also be said to be a process in humanizing human activities. This is in line with the Law of the Republic of Indonesia Number 20 of 2003 concerning Article 1 National Education System paragraph 1 states, Education is a conscious and planned effort to create a learning atmosphere and learning process so that students actively develop their potential to have religious spiritual strength, self-control, personality, intelligence, noble character, and skills needed by themselves, society, nation and country.

These achievement efforts, the world of education are expected to be an integral part of people's lives in the global era that must be able to provide and facilitate the growth of intellectual, social and personal skills. These skills are built not only on the basis of ratios and logic, but also inspiration, creativity, morals, intuition (emotions) and spiritual.

Judging from the level of education, the Central Statistics Agency as of February 2016 showed that the open unemployment rate reached 7,024,172, as many as 695,384 people or 8.54 percent of whom were from scholars. In addition, the number of unemployed undergraduates in 2016 increased compared to the position of previous years. Based on BPS data shows that in August 2015 undergraduate unemployment was only 7.83 percent ".

The main problem of entrepreneurship education in Indonesia is the mindset of most Indonesian people that the goal of continuing education to higher education to become a civil servant is not to be someone who has an entrepreneurial mentality (Jufri, Akib, Ridjal, Sahabuddin, \& Said, 2018; Rengifurwarin, Akib, Jasruddin, \& Salam, 2018; A. Syam, Akib, Yunus, \& Hasbiah, 2018; H. Syam, Akib, Patonangi, \& Guntur, 2018; H. Syam et al., 2018). This is formed, because they see entrepreneurship as a mere business or business, but not only limited to that, but new entrepreneurs now are individuals who have creative and innovative power, seek opportunities and take risks and other entrepreneurial characters not solely for the interests of the business world, but every job that has enthusiasm, mindset and entrepreneurial character will make a difference, change and positive growth in their profession and work outside the realm of business.

Entrepreneurship learning will be encouraged in higher education so that college graduates are able to be independent. Entrepreneurship learning in higher education is expected to be able to prepare students to dare to be independent, no longer focused on becoming job seekers. Moreover, data on educated unemployment in Indonesia shows, the higher a person's education, the lower the independence and entrepreneurial spirit (Klein, Mahoney, McGahan, \& Pitelis, 2010; Schnellenbach, 2007; Windrum \& Koch, 2008).

Based on data from the number of Makassar State University (UNM) students with the number of senders of Student Creativity Program (PKM) proposals as one barometer the motivation of students to entrepreneurship is very small. On the other hand, students are expected to be motivated by entrepreneurship as a solution to reduce unemployment. 
Table 1.

Number of Students and Number of Submitters of the Last Two Years of PKM Proposals (2015-2016)

\begin{tabular}{|c|l|c|c|c|c|c|c|}
\hline \multirow{2}{*}{ No } & \multirow{2}{*}{ Faculty } & \multicolumn{3}{|c|}{2015 Year } & \multicolumn{3}{c|}{ 2016 Year } \\
\cline { 3 - 8 } & & $\begin{array}{c}\text { Number } \\
\text { of } \\
\text { students }\end{array}$ & $\begin{array}{l}\text { Number } \\
\text { of Titles }\end{array}$ & $\mathbf{\%}$ & $\begin{array}{c}\text { Number } \\
\text { of } \\
\text { students }\end{array}$ & $\begin{array}{c}\text { Number } \\
\text { of Titles }\end{array}$ & $\%$ \\
\hline 1 & FMIPA & 688 & 155 & 22,53 & 681 & 136 & 19,97 \\
\hline 2 & FT & 611 & 148 & 24,22 & 807 & 382 & 47,34 \\
\hline 3 & FIK & 556 & 4 & 0,72 & 682 & 1 & 0,15 \\
\hline 4 & FIP & 672 & 9 & 1,34 & 726 & 47 & 6,48 \\
\hline 5 & FBS & 490 & 27 & 5,51 & 551 & 18 & 3,27 \\
\hline 6 & FIS & 448 & 4 & 0,89 & 615 & 6 & 0,98 \\
\hline 7 & Fpsi & 154 & 111 & 72,08 & 136 & 21 & 15,44 \\
\hline 8 & FSD & 200 & 9 & 4,5 & 241 & 0 & 0,00 \\
\hline 9 & FE & 577 & 20 & 3,47 & 614 & 43 & 7,00 \\
\hline \multicolumn{2}{|c|}{ Total } & $\mathbf{4 . 3 9 6}$ & $\mathbf{4 8 7}$ & $\mathbf{1 1 , 0 8}$ & $\mathbf{5 . 0 5 3}$ & $\mathbf{6 5 4}$ & $\mathbf{1 2 , 9 4}$ \\
\hline
\end{tabular}

Information:

FMIPA: Faculty of Mathematics and Natural Sciences

FT: Faculty of Engineering

FIK: Faculty of Sports

FIP: Faculty of Education

FBS: Faculty of Languages and Literature

FIS: Faculty of Social Sciences

FPsi: Faculty of Psychology

FSD: Faculty of Art and Design

FE: Faculty of Economics

Source: Planning Sub Division and Assistant Chancellor for Student Affairs, UNM, 2017

Entrepreneurship learning at UNM must be able to provide knowledge in cognition and applicative understanding in entrepreneurship. (Seikkula-Leino, Ruskovaara, Ikavalko, Mattila, \& Rytkola, 2010), that entrepreneurship is a scientific discipline, like other disciplines, entrepreneurship can be learned. The learning theory proposed by Kimble that a behavior change is relatively fixed and is a result of repeated practices (McLean \& Christensen, 2017; Murgu, Kurman, \& Hasan, 2018; Oneto et al., 2017).

In order to follow rapid changes and overcome unemployment, the government seeks to equip entrepreneurial knowledge and skills in formal education (Akib, 2005; Dharma \& Akib, 2009). The implementation of education including the process of entrepreneurship learning is not only the responsibility of the leaders of educational institutions, educators and educational administration institutions that organize education itself, but also the responsibility of parents, the community, and the government (Rachman, Nawawi, Arismunandar, \& Akib, n.d.; Rengifurwarin et al., 2018; A. Syam et al., 2018; H. Syam, Gani, \& Akib, 2019).

Makassar State University (UNM) is one of the higher education institutions that applies 


\section{4 | Jurnal Administrare: Jurnal Pemikiran Ilmiah dan Pendidikan Administrasi Perkantoran \\ Volume 6 No. 1 January-June 2019. Pages 51-60}

entrepreneurship courses as courses taught in each study program. This is also in line with UNM's vision, namely, as a center for education, study, and development of education, science, technology, and art with an educational and entrepreneurial perspective.

However, the problem that arises is that the entrepreneurship learning movement in higher education that has been carried out has not yet produced the expected results. Entrepreneurship learning has not been able to change the mind-set of college graduates from finding jobs (job seekers) to creating jobs (job creators).

Education is a form of long-term investment (long-term investment), meaning that investment in the field of human resources cannot be enjoyed immediately. But in the long run it is believed that the benefits will soon be detected, namely by preparing quality human resources through quality education channels in the future, of course all pillars of the nation's strength must make the maximum investment to improve the quality (process and results) of education.

\section{METHOD}

The approach in this study is a quantitative approach. The research that will be conducted includes two variables. Following are the definitions and indicators of variables that will be used in this study. 1) Entrepreneurship learning (X) is the process of changing the formation of knowledge, skills, attitudes and abilities in entrepreneurship, with indicators; learning material, learning models, and learning evaluation. 2) Decision making (Y), is a thought process in solving problems to obtain the results to be implemented, with indicators; intelligence, design, and choosing. The population in this study were all Makassar State University students who submitted the 2016 Student Creativity Program (PKM) title totaling 654 people. The total sample is 242 people. Data collection techniques used are, observation, questionnaire, and documentation Data analysis using SEM.

\section{RESULT AND DISCUSSION}

Based on this study, the tendency of respondents strongly agreed that entrepreneurship learning with three indicators namely; teaching materials, teaching models, and evaluation of learning were carried out very well at Makassar State University. The results of these studies are in line with (A. Syam et al., 2018), there are two ways to instill an entrepreneurial mentality with students on campus. First, integrating entrepreneurship education into the curriculum. In the curriculum, the scientific character of entrepreneurship should be designed to know to do, to do, and to be an entrepreneur. The purpose of education to know and to do is integrated in the curriculum of the study program, distributed in various scientific subjects. Higher Education provides entrepreneurship courses aimed at providing motivation and forming entrepreneurial mental attitudes. For the purpose of the be entrepreneur, training is provided in practical business skills. Secondly, student extracurricular activities need to be systemically packaged and directed towards building entrepreneurial motivation and mental attitude. Guidance of students in various activities of interest and talent, science, welfare or organization should also be directed to provide entrepreneurship skills. 
Constructivist approach, contextual, cooperative in learning entrepreneurship at UNM can be seen as a process of change and formation of knowledge, skills, attitudes and abilities of an entrepreneur, either through education, training, mentoring, or experience.

Entrepreneurship education is a weapon that destroys unemployment and poverty, and becomes a ladder to the dream of every society to be financially independent, have the ability to build individual prosperity, as well as contribute to building people's welfare (Jufri et al., 2018; Lewis, Hoover, Moses, \& Rickover, 1980; Rengifurwarin et al., 2018; Seikkula-Leino et al., 2010; A. Syam et al., 2018).

\section{Student Decision Making in Entrepreneurship}

Based on the results of this study, the tendency of respondents strongly agreed that decision making with three indicators namely; intelligence, design, and choosing are the things that underlie respondents to make decisions in entrepreneurship.

The results of this study are in line with the opinion of (Simon, 1979) who conceptualized three main stages in the process, decision making:

1. Intelligence activity. Simon describes this initial stage as a search for environmental conditions that require decision making.

2. Design activities. During the second phase, there may be a problem discovery, development and analysis.

3. Activities to choose. This third and final stage is an actual choice - choosing certain actions from those available

Recent empirical research indicates that decision processes that include making strategic choices produce good decisions. Returning to the dominant role that information technology plays in the analysis and practice of effective decision making, the relevance of studies and the application of organizational behavior is what is called decision-making behavior.

\section{Measurement Model Coefficient Test Results}

In this study used a SEM model with a second order. Exogenous variables and endogenous variables. Testing the goodness of fit in the measurement model for each variable uses the convergent validity measurement which is presented as follows. This evaluation is done by looking at the value of the loading factor for each indicator. If the value is greater than 0.50 , it can be said that the indicator is valid. Convergent Validity aims to ensure that the indicators used correctly define the latent variables observed.

The value of loading factor on all Entrepreneurship Learning variable indicators (X1) is above 0.5 with a sig value $<0.05$. This shows that the existing sub-variables in Entrepreneurship Learning (X) have valid indicators and can form these variables well. The value of loading factors on all indicators of Decision Making variable (Y) is above 0.5 with a sig value $<0.05$. This shows that the sub-variables that exist in Decision Making (Y) have valid indicators and can form these variables well. 


\author{
56 Jurnal Administrare: Jurnal Pemikiran Ilmiah dan Pendidikan Administrasi Perkantoran \\ Volume 6 No. 1 January-June 2019. Pages 51-60
}

\title{
Results of Structural Model Analysis
}

Based on the results of statistical tests that have been used, all hypotheses tested meet the requirements or can be used as measurement models in this study. Overall, the model in this study is divided into direct influence and indirect influence.

1. The Relationship between Entrepreneurship Learning to Decision Making has a positive path coefficient $(0.211)$ and a p-value of $0.015<0.05$. It can be concluded that there is a significant positive influence between the Entrepreneurship ranks on Decision Making.

2. The Relationship between Entrepreneurial Motivation towards Decision Making has a positive path coefficient $(0.591)$ and a p-value of $0,000<0.05$. It can be concluded that there is a significant positive effect between Entrepreneurial Motivation on Decision Making.

3. The Relationship between Entrepreneurial Interest and Decision Making obtained a positive path coefficient $(0.161)$ and a p-value of $0.014<0.05$. It was concluded that there was a significant positive effect between Entrepreneurial Interest on Decision Making.

4. In the relationship of exogenous variables Entrepreneurship Learning and Entrepreneurial Motivation obtained a correlation value of 0.849 and p-value of $0.000<0.05$, it can be concluded that there is a very strong positive relationship between Entrepreneurship Learning and Entrepreneurial Motivation.

In addition to testing the direct effect, in SEM also known the indirect effect of indirect influence is the result of multiplying direct effects. Indirect influence is significant if the two direct influences that make it up are significant.

1. Indirect Impact of Entrepreneurship Learning on Decision Making through Entrepreneurial Interest and obtained indirect effect coefficient of 0.071. This is explained by the existence of a significant direct influence between Entrepreneurship Learning on Entrepreneurial Interest and the direct influence of Entrepreneurial Interest on Decision Making, so it can be concluded that there is a significant indirect effect between Entrepreneurship Learning on Decision Making through Entrepreneurial Interest.

2. Indirect Effects of Entrepreneurial Motivation on Decision Making through Entrepreneurial Interest and obtained an indirect effect coefficient of 0.071. This is explained by the significant direct effect of Entrepreneurial Motivation on Entrepreneurial Interest and the direct influence of Entrepreneurial Interest on Decision Making, so it can be concluded that there is a significant indirect effect between Entrepreneurial Motivation on Decision Making through Entrepreneurial Interest. 


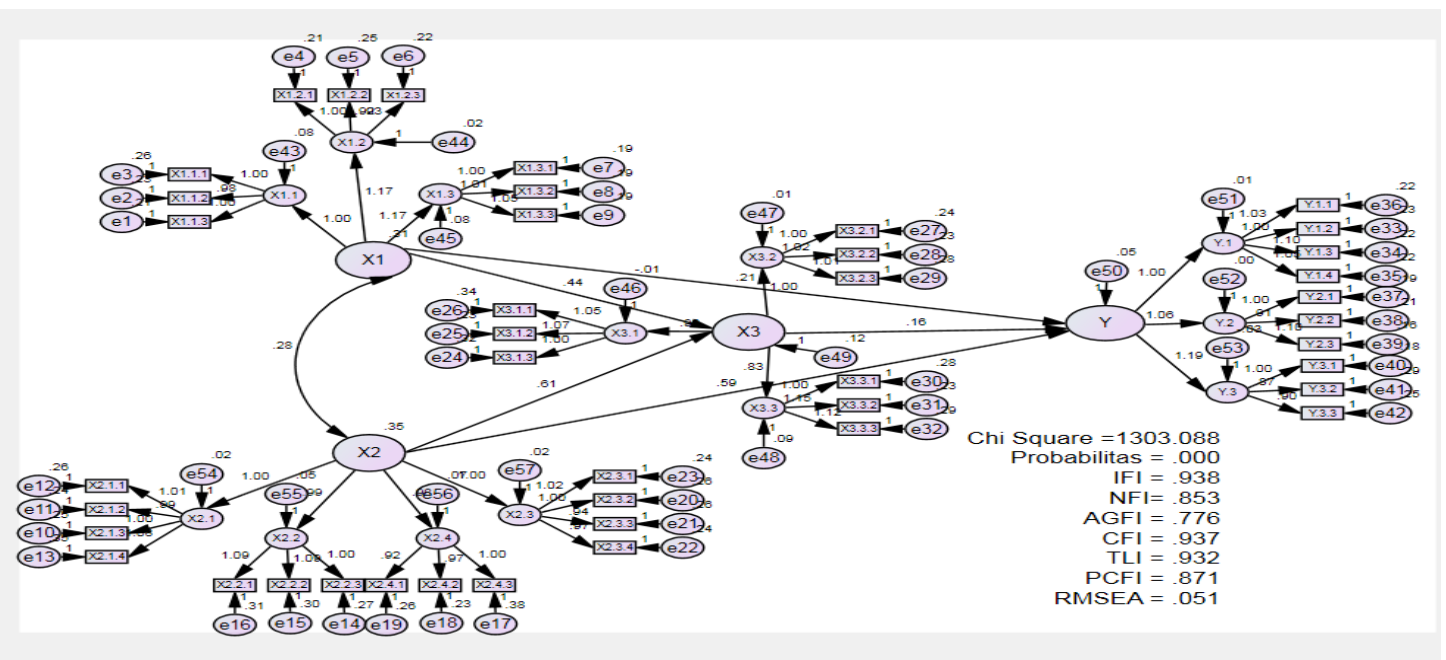

Picture 1 Structural Model

Furthermore, the final results of the path diagram that are formed can be seen on the following page.

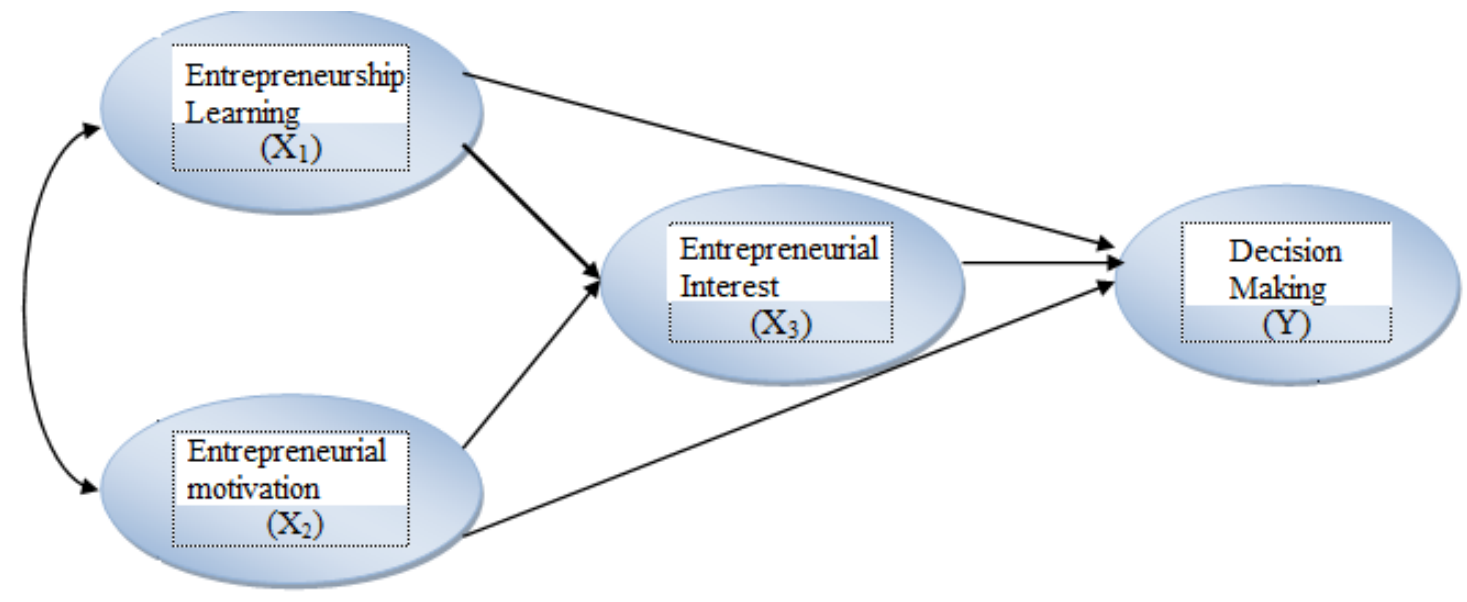

\section{Hypothesis testing}

Figure 2. End Result Path Chart

Based on the empirical model proposed in this study, testing of the hypothesis proposed through testing path coefficients in structural equation models can be tested. The entire model tested by the five direct paths has a significant effect, and the two indirect pathways all have a significant effect. The interpretation can be explained that, "Entrepreneurship Learning has a positive and significant influence on Decision Making with $\mathrm{P}=0.015<0.05$ with a coefficient 


\author{
58 | Jurnal Administrare: Jurnal Pemikiran Ilmiah dan Pendidikan Administrasi Perkantoran \\ Volume 6 No. 1 January-June 2019. Pages 51-60
}

of 0.211 , this means that the better the process of learning entrepreneurship, the more solidify students in making decisions for entrepreneurship with coefficients 0.211 ".

\title{
Discussion
}

The results of the study show that entrepreneurship learning has a significant influence on student decision making in entrepreneurship. This is in line with the level of enthusiasm of UNM students to take part in PKM which is increasing every year, although there are some faculties that have decreased in terms of submitting PKM proposals.

The SCL learning paradigm with constructivism, contextual and cooperative approaches can provide color in learning entrepreneurship at UNM. With this method, entrepreneurship learning is not only limited to lecture rooms but can also be done outdoors which can provide new nuances while creating PAIKEM learning, which is active, innovative, creative, effective, and fun learning.

Entrepreneurial learning is one way to grow entrepreneurial interest, basically for everyone because it can be learned. (Drucker, 2014) Innovation and Entrepreneurship that, "Every person who has the courage to make decisions can learn to be an entrepreneur, and behave like an entrepreneur. Because (or hence) entrepreneurship is more a behavior than a personality symptom, which basically lies on concepts and theories, not on intuition ". Education that has entrepreneurial insight, is education that applies principles and methodology towards the formation of life skills for students through an integrated curriculum developed on campus (Jufri et al., 2018; A. Syam et al., 2018).

The results of a study conducted by (Kuratko, Morris, \& Schindehutte, 2015) show that alumni taking entrepreneurship courses have high rankings on most indicators of entrepreneurship, findings make justification and give some credence to the high interest in entrepreneurship by universities and other higher education institutions, the policy is indigenous in Zimbabwe encouraging youth to start their own businesses also seems to have an impact on graduates' entrepreneurial intentions. Advise the College must make core entrepreneurship education and integral components of curriculum studies for all students regardless of the origin of their chosen study area.

\section{CONCLUSION}

Entrepreneurship learning influences student decision making in entrepreneurship. In an effort to change the student mindset to become a job creator, entrepreneurship learning presents Active, Innovative, Creative, Effective and Enjoyable Learning (PAIKEM) so that the goals of learning that are to be entrepreneurship can really be achieved.

\section{REFERENCES}

Akib, H. (2005). Perilaku kreativitas organisasi berbasis pengetahuan: pengaruh struktur, budaya, dan iklim organisasi terhadap perilaku kreativitas pegawai pada perusahaan Bosowa Group.

Dharma, S., \& Akib, H. (2009). Kewirausahaan Berbasis Kreatifitas Dan Inovasi. Jurnal 
Pendidikan Dan Kebudayaan, 15.

Drucker, P. (2014). Innovation and entrepreneurship. Routledge.

Farida, U. (2017). Analysis of Empowerment Program that was Implemented in Mamuju Regency East Sulawesi Indonesia. 149(Icest), 19-21.

Jufri, M., Akib, H., Ridjal, S., Sahabuddin, R., \& Said, F. (2018). Improving attitudes and entrepreneurial behaviour of students based on family environment factors at Vocational high school in Makassar. Journal of Entrepreneurship Education.

Klein, P. G., Mahoney, J. T., McGahan, A. M., \& Pitelis, C. N. (2010). Toward a theory of public entrepreneurship. European Management Review, 7(1), 1-15.

Kuratko, D. F., Morris, M. H., \& Schindehutte, M. (2015). Understanding the dynamics of entrepreneurship through framework approaches. Small Business Economics, 45(1), 1-13.

Lewis, E., Hoover, J. E., Moses, R., \& Rickover, H. G. (1980). Public entrepreneurship: Toward a theory of bureaucratic political power (Vol. 9). Indiana University Press Bloomington.

McLean, A. N., \& Christensen, J. W. (2017). The application of learning theory in horse training. Applied Animal Behaviour Science, 190, 18-27. https://doi.org/https://doi.org/10.1016/j.applanim.2017.02.020

Murgu, S. D., Kurman, J. S., \& Hasan, O. (2018). Bronchoscopy Education: An Experiential Learning Theory Perspective. Clinics in Chest Medicine, 39(1), 99-110. https://doi.org/https://doi.org/10.1016/j.ccm.2017.11.002

Niswaty, R., Rusbiati, S., Jamaluddin, J., \& Salam, R. (2017). The Influence of Teacher's Reinforcement for Students Motivation. International Conference on Education, Science, Art and Technology, 148-152.

Oneto, L., Navarin, N., Donini, M., Sperduti, A., Aiolli, F., \& Anguita, D. (2017). Measuring the expressivity of graph kernels through Statistical Learning Theory. Neurocomputing, 268, 4-16. https://doi.org/https://doi.org/10.1016/j.neucom.2017.02.088

Rachman, E., Nawawi, J., Arismunandar, A. K., \& Akib, H. (n.d.). Autonomy of Private Higher Education Management: Financial Accountability Perspective.

Rengifurwarin, Z. A., Akib, A. H., Jasruddin, U. N. M., \& Salam, R. (2018). Snapshot of Public Service Quality in The Center For Integrated Business Service (CIBS), Cooperative Micro Small and Medium Enterprises (CMSME), Maluku Province, Indonesia. Journal of Entrepreneurship Education, 21(3).

Saggaf, M. S., Salam, R., \& Rifka, R. (2017). The Effect of Classroom Management on Student Learning Outcomes. International Conference on Education, Science, Art and Technology, 98-102.

Salam, R., Rosdiana, Suarlin, \& Akib, H. (2014). The Impact Of Policy on Region Expansion to Office Administrative Services in Barombong Subdistrict of Gowa District. International Conference on Mathematics, Sciences, Technology, Education and Their Applications, 1(1), 505. State University of Makassar. 
60 Jurnal Administrare: Jurnal Pemikiran Ilmiah dan Pendidikan Administrasi Perkantoran Volume 6 No. 1 January-June 2019. Pages 51-60

Schnellenbach, J. (2007). Public entrepreneurship and the economics of reform. Journal of Institutional Economics, 3(2), 183-202.

Seikkula-Leino, J., Ruskovaara, E., Ikavalko, M., Mattila, J., \& Rytkola, T. (2010). Promoting entrepreneurship education: the role of the teacher? Education+ Training, 52(2), 117-127.

Simon, H. A. (1979). Rational decision making in business organizations. The American Economic Review, 69(4), 493-513.

Syam, A., Akib, H., Yunus, M., \& Hasbiah, S. (2018). Determinants of entrepreneurship motivation for students at educational institution and education personnel in Indonesia. Journal of Entrepreneurship Education.

Syam, H., Akib, H., Patonangi, A. A., \& Guntur, M. (2018). Principal Entrepreneurship Competence Based on Creativity and Innovation in the Context of Learning Organizations in Indonesia. Journal of Entrepreneurship Education, 21(3), 1-13.

Syam, H., Gani, H. A., \& Akib, H. (2019). Public Entrepreneurship: What, Why and How. International Conference on Education, Science and Technology (ICESTech). Konvensi Nasional Pendidikan Indonesia (KONASPI) IX 2019. Padang.

Windrum, P., \& Koch, P. M. (2008). Innovation in public sector services: entrepreneurship, creativity and management. Edward Elgar Publishing. 